\title{
Encounter with Paulo Freire's Critical Pedagogy: Visiting the Brazilian Social Context (1950s-1970s)
}

\author{
Yi-Huang Shih \\ Department of Early Childhood Educare, Ching Kuo Institute of Management and Health, Taiwan
}

Received January 16, 2020; Revised February 19, 2020; Accepted February 24, 2020

Copyright $\odot 2020$ by authors, all rights reserved. Authors agree that this article remains permanently open access under the terms of the Creative Commons Attribution License 4.0 International License

\begin{abstract}
The wisdom and courage that Freire expressed when criticizing the structure of oppression were actually rooted in a very real-life experience. Of course, this kind of life experience includes Freire's life in Brazil. Thus, the background of this research is that the development of Paulo Freire's critical pedagogy was closely related to the political, social, and economic oppression in parts of Latin America. From this we can understand that Freire's critical pedagogy was intimately related to the Brazilian social context. So the purpose of this paper intends to visit the Brazilian social context (1950s-1970s) sand explore its influence on Paul Freire's critical pedagogy. Secondly, it aims to illuminate its implications for education. In order to complete this research purpose, the documentary analysis method is used by the author. Furthermore, the principal results of this paper are to discuss implications for education. The implications are as follows: (1) education should build a more just society; (2) education is to let students change from "being for others" to "being for themselves", and (3) pay much attention to justice in the teacher-student relationship. In conclusion, this paper contributes to the field of the exploration of Paulo Freire's critical pedagogy by considering the historical, political, cultural, social, economic, educational, and religious aspects. This paper discusses some implications for education. These are important aspects of the research.
\end{abstract}

Keywords Critical Pedagogy, Paulo Freire, the Brazilian Social Context

\section{Introduction}

The origins of the philosophy of education and critical pedagogy can be traced back to the time of Plato and Socrates. These two philosophers recognised the importance of dialogue in human interaction and education. Indeed, it is well-known that dialogue is something that is indispensable to critical pedagogy, as pointed out by Paulo Freire (Guilherme, 2017).

In the Republic, Socrates challenged his student Plato to think critically about educational, social and philosophical issues and advocate overtly through the figure of the philosopher-king, which philosophers are a "special kind" due to their capacity to critically analyze issues. This aspect, namely to think critically about educational, social and philosophical issues, is a cornerstone of critical pedagogy. However, it was in the 1960s and 70s that critical pedagogy truly emerged as a theory and a distinct field of study, and this emergence is directly related to the works of Freire (Guilherme, 2017). The well-established image of Freire is as a progressive, radical, or even revolutionary educator (Esteva, Stuchul \& Prakash, 2005). Many people have been moved by Paulo Freire's political courage and intellectual reach were matched by a love of life and generosity of spirit. The political and personal mutually informed Freire's life and work. Freire assumed the role of a critical teacher (Giroux, 2010). Freire's role as an intellectual is intimately connected with his ontology and ethics, his educational theory, and his political practice. Freire's principal concern is with the development of what might be called the critical intellectual. What does this mean? Freire encourages those undertaking intellectual work to adopt a curious, investigative, probing, searching, and restless attitude toward the world (Roberts, 2010). As Freire moved between the private and the public, he revealed an astonishing gift for making everyone he met feel valued. His very presence embodied what it meant to combine political struggle and moral courage to make hope meaningful and despair unpersuasive (Giroux, 2010).

Freire is the exemplary organic intellectual of our time. If Antonio Gramsci had not coined this term, we would have to invent it to describe the revolutionary character and moral content of the work and life of Freire. It is safe to say that his classic work, Pedagogy of the Oppressed, 
was a world-historical event for counter-hegemonic theorists and activists in search of new ways of linking social theory to narratives of human freedom (West, 1993). And the wisdom and courage that Freire expressed when criticizing the structure of oppression were actually rooted in a very real-life experience. Of course, this kind of life experience includes Freire's life in Brazil, and his life was of course influenced by the social context in Brazil. Therefore, the Brazilian social context was bound to affect the shaping of his critical pedagogy. To better understand Freire's critical pedagogy, this paper returns to visit the Brazilian social context (1950s-1970s) and critically analyzes and interprets the historical, political and cultural situation, as well as the aspects of social structure, economics, education, and religious beliefs. Finally, this paper discusses implications for education.

\section{Visiting the Brazilian Social Context (1950s-1970s) to Encounter with Paulo Freire's Critical Pedagogy}

In order to understand the Brazilian social context (1950s-1970s) that brought about Freire's critical pedagogy, this paper intends to discuss from the following levels:

\subsection{Historical, Political and Cultural Situation}

The historical development of Brazil can be divided into the colonial period (1500-1822), the imperial period (1822-1889), the republican period (1889-1963), the dictatorship of the military government (1964-1984) and 1985 to present.

First, regarding Brazil's land and population, the country has a large population and is the largest country in South America. Compared with other countries in the world, Brazil has the highest number of territories and distinct populations (Haussman \& Haar, 1978). Brazil was first discovered by the Portuguese explorer Pedro Alves Cabral in April 1500 (Bender, 1990; Havighurst \& Moreira, 1965). Brazil then became a Portuguese colony. During the 300-plus years of Portuguese colonization (1500-1822), Brazil developed under the influence of the Portuguese political system. It was not separated from Portugal until 1822 when it became an independent country (Mackie, 1981), thus entering the so-called imperial period.

Second, regarding the political situation in Brazil, since the 16th century when the Portuguese colonized the country, Brazil was successively ruled by the colonial system. The main ethnic groups that have shaped Brazilian culture are Portuguese, Indian (native), and African (Haussman \& Haar, 1978). In the early 1960s (1961-64), when President J. Goulart began fierce reform, a series of political commotions began. Brazil's right-wingers were plotting to overthrow the Goulart government. Due to serious inflation and domestic political struggles, political and social turmoil and economic crisis lasted more than two years. In this economic and social turmoil, the Brazilian military launched a military coup in March 1964, ending short-term parliamentary democracy in Brazil after the war, and began a period of dictatorship by the military. Brazil then fell into a period of autocratic social development. Among the features of this period, power was still concentrated in the hands of a few elites (Hall \& Garcia, 1989; Huang, 2003). In terms of the voter turnout rate, the number of people who voted during the Republican period was only 5\% (Haussman \& Haar, 1978). This rate increased to $16 \%$ in 1945 , and then to $25 \%$ in 1962 . Moreover, as of 1990 , the percentage of the population that voted in Brazil only accounted for about $48 \%$ of the total population. Still, the voting rights of $23 \%$ of the people in the country were deprived under the political and social system (Wang, 1990). From this, it can be seen that power is still concentrated in the hands of a few elites. Freire (1993) pointed out: "For some people, democracy is the process of seeking equality in the social unjust system." However, as far as Brazil's political system is concerned, some politicians still use national resources to maintain their own power and use this power to gain private benefits (Carnoy, 1997), prompting Brazil to become a closed society with power concentrated in the hands of a small number of people. There are many ills including injustice and inequality. Freire believed that Brazil could not be an open society because of its lack of democratic experience. And the lack of democratic experience is a major obstacle to the democratization of Brazil. According to Freire's judgment, this lack of democratic experience kept Brazilian's consciousness at a naive level. No wonder Freire pointed out the false democratization and corruption in his country (Freire, 1992, 1997).

Furthermore, regarding the cultural situation in Brazil, Brazil is the only Portuguese-speaking country in South America. Its customs and traditions are different from those of neighboring Spanish-speaking countries. However, before the Europeans arrived in Brazil, Indian Native Americans already lived in Brazil. In addition, Africans were sent to Brazil as slaves. These slaves also integrated their customs and language into the Brazilian lifestyle. The uniqueness of Brazil is due to the integration of these different ethnic groups (Bender, 1990). Thus, we can see the diversity of Brazilian ethnicity. Brazil has not only been colonized by various cultures, but has also become a cultural melting pot. To get an understanding of the nature of this cultural melting pot, we can examine Brazilian religious practices. Freire pointed out that Brazil had always been an extremely authoritarian society and had developed a culture of silence at that time. This could be described as the historical culture of Brazil (Freire, 
1985; Shor \& Freire, 1987). As far as elite politics is concerned, Brazil was essentially an empire-oriented country during the colonial period as well as in the later imperial and republican periods (Haussman \& Haar, 1978).

To sum up, Freire (1997) pointed out: "The rise of democracy in Brazil depends on the development of the economy, and when democracy improves, it can end the oppressive forces imposed on the poor by the rich." Freire's life work was for the democratization of Brazil. Freire raised the critical consciousness of Brazilians through his critical pedagogy. When people in Brazil become more critical, they would be more capable of transforming their world and making it more democratic.

\subsection{Social Structure}

Regarding the social structure of Brazil, although slavery was abolished in 1888 , the social structure of Brazil still has obvious stratification. There are many illiterate people. Landless laborers work for a small number of wealthy people and landowners, so life situations can be very tragic for the poor (Mackie, 1981). In 1956, half of the country's land was owned by $3 \%$ of the population. Only a small part of the land could be reclaimed (Elias, 1994), and therefore the gap between rich and poor grew. In addition, in terms of social stratification in Brazil, since the Second World War, the social stratification in Brazil has become more and more clear. In the process of industrialization, urbanization, and modernization, the overall social structure of Brazil has undergone major changes. In fact, Brazil was divided into five social classes at that time (Haussman \& Haar, 1978), as illustrated below in Table 1 .

Table 1. Table of Social Class Differentiation in Brazil

\begin{tabular}{|l|l|}
\hline Class & The Explanation of Class Characteristics \\
\hline Upper Class & $\begin{array}{l}\text { Large landowners and those who live in the } \\
\text { upper class in the city }\end{array}$ \\
\hline Upper-Middle Class & $\begin{array}{l}\text { Suburban landowners who have } \\
\text { medium-sized land holdings and upper-level } \\
\text { professionals and businessmen }\end{array}$ \\
\hline Lower-Middle Class & $\begin{array}{l}\text { Public officials, small businessmen and } \\
\text { manufacturers, lower level professionals, and } \\
\text { not-rich suburban property owners }\end{array}$ \\
\hline Upper-Working Class & $\begin{array}{l}\text { Workers in factories, railways, government } \\
\text { agencies and transportation }\end{array}$ \\
\hline Lower-Working Class & $\begin{array}{l}\text { Agricultural land workers and unskilled } \\
\text { urban laborers }\end{array}$ \\
\hline
\end{tabular}

Source: Haussman \& Haar (1978).

Since the 1930s, industrialization, urbanization, and population growth changed Brazil's appearance (Time-Life Books, 1986). However, economic modernization exacerbated the gap between the rich and the poor and led to cultural imbalances. Quality of life of the Brazilian people depends on economic income, but according to the government's economic standards, half of
Brazil's population was considered poor (Bender, 1990). In addition, the development of urbanization caused the Brazilian people to concentrate on a few modern metropolises, which intensified the differences in life between villages and cities. Farmers in rural areas lived in extreme poverty and had fewer opportunities for upward mobility (Haussman \& Haar, 1978). Generally, the blacks were even poorer, and they could be said to be the lowest class in society. In Brazil, poverty was not relative, but absolute, and the poor often went hungry for a long time (Time-Life Books, 1986).

In the case of a clearly defined social class in Brazil, Freire expressed his opposition to radical opposition toward a class-based society because it would create a violent society (Freire, 1996), which in turn would make the rich even richer economically. The poor were getting poorer, and the gap between rich and poor was getting bigger; the poor were bound to suffer from poverty and hunger (Time-Life Books, 1986). The oppression of the poor by the rich in Brazil had formed a culture of silence. In a culture of silence, the poor take being exploited by the rich for granted. And they do not know how to resist this unjust situation. Freire raised the critical consciousness of the poor through his critical pedagogy. Freire hoped that the poor could be aware of the oppression of the rich and thus eliminated inequalities within the social structure.

\subsection{Economics}

Brazil is very special in many respects, such as being one of the world's newest industrial economic countries with extremely rich and poor people. Urbanization has further exacerbated the gap between rich and poor in Brazil. Furthermore, compared with other countries in the world, Brazil has the most unfair income distribution (Carnoy, 1997). Thus, some of the poorest people in the Western Hemisphere live in the northeast of Brazil, and their levels of poverty are quite surprising. Northeastern Brazil can be described as one of the poorest regions in the world (Mackie, 1981; Mitchell, 1981).

In the context of Brazil's economic development, Freire believed that Brazil's economic development could contribute to the promotion of democracy in Brazil. However, when people look at Brazil's economic development during the colonial rule, the Portuguese government upheld mercantilistism at that time and did not allow the development of manufacturing industries. The wealthy landowners in Brazil also thought that industry was the science and technology of developed countries in Europe and North America, and they believed that it was inappropriate to develop industry and compete in Brazil. Brazil's economy was stalled by the colony's dependence, and its traditional position in the world has been to supply raw materials to European and North American industrial countries (Data Center for Africa and 
Latin America, 1963; Freire, 1997).

In the early years of independence in Brazil, the slaves were liberated, and there was a lack of farming labor. Even the agricultural economy that had once survived was deeply affected. Many political leaders were novices, with no connection with the old regime. The result was political chaos. Immigrants from Europe who hoped to help Brazil's economy were still unfamiliar with the local situation. During this period, the government had no economic policies to follow and took no step-by-step economic measures. Therefore, in the 30 years after Brazil reorganized its republican economy, the economic situation was chaotic without any substantial achievements. The reason for the chaos in Brazil's economy was due to huge foreign debt, the high rate of inflation, and unequal distribution of wealth. Furthermore, the development of education has inevitably been unable to avoid the impact of the above-mentioned economic turmoil, which makes it impossible to improve the quality and quantity of education (Bender, 1990; Data Center for Africa and Latin America, 1963; Freire, 1998b).

Therefore, to improve education in Brazil, it is necessary to improve the Brazilian economy. To improve the Brazilian economy, there is a need to improve the uneven distribution of people's income. Under such circumstances, it is necessary to enhance the literacy of the people and their ability to read the world. Freire raised people's ability to read the world of Brazilians through his critical pedagogy. Freire hoped that the education in Brazil would improve and the economic development of Brazil would be enhanced.

\subsection{Education}

During the Portuguese colonial period in Brazil, Portugal did not intend to develop Brazil into a civilized society. It only attempted to obtain benefits from the Brazilian land (Freire, 1997). Thus, under colonialism, Portugal exploited Brazil rather than invest in it. Therefore, Portugal's investment in Brazilian education was of little concern (Haussman \& Haar, 1978). In other words, it can be said that Portugal did not intend to educate the Brazilian people, but only tried to occupy Brazil and exploit Brazil. As a matter of fact, although the Portuguese colonists lived in Brazil, their vision did not include the development of Brazil or the community of life there (Freire, 1997). Therefore, more than half the people in Brazil were still illiterate. Illiteracy in Brazil is mostly a continuation of this kind of tradition. Portugal did not pay attention to the progress of Brazilian culture. Therefore, its vision did not extend to education development in Brazil. Furthermore, Brazilian society was dominated by agriculture, and educational opportunities were often reserved for members of the aristocracy who were elites with power in the country, the church, and in different professional fields. In addition, the education these people did receive was more decorative than functional in nature. In other words, the education they received was only a symbol of social status. This symbol was then used to separate upper classes and lower classes (Haussman \& Haar, 1978). However, the level of education of the common people (lower class) had fallen to the extreme. Therefore, in Brazil, there was a stark contrast between the small number of literati and the vast majority of illiterate people.

As far as Brazil's educational development model is concerned, it was created during the colonial period based on European culture (Haussman \& Haar, 1978). As for the tertiary system of Brazilian education, its choice of rules, examination system, and degree system were mainly influenced by France. In addition, the connotation and form of the school subjects were influenced by the core groups of French intellectuals who also had a profound influence on the development and expansion of Brazilian universities. During the expansion of the University of Brazil, these intellectuals became the cornerstones of the elite (Taylor, 1993). For this reason, Brazil's education was often classist in essence; in terms of orientation, it was elitist. Therefore, the vast number of illiterate people in Brazil's lower classes strongly contrasted with the elites of the upper classes. The illiterate people in Brazil did not know that they lived in a culture of silence. In the silent culture, the illiterate was often divided into individuals. They could not transform or even create the world they lived in (Freire, 1985; Haussman \& Haar, 1978).

In 1960, illiterate people in Brazil accounted for $75 \%$ of the population (Elias, 1994). No wonder some scholars criticized the Brazilian education system as a somnolent educational system, which means that the Brazilian education system could not keep pace with the needs of a changing society (Haussman \& Haar, 1978) or effectively solve the problem of illiteracy. Therefore, education in Brazil has long been characterized by high illiteracy rates and low educational standards. Moreover, the illiterate did not have the right to vote, thus prompting Brazil to become a closed society, lacking democratic experience. Education was therefore seen as a means of resolving this phenomenon. In fact, most young people in Latin America (including Brazil) were aware that the above-mentioned problems were not due to people's laziness. People were not inferior but lacked education (Elias, 1994; Freire, 1985). Therefore, education was also seen as a way to solve this phenomenon. Freire (1997) further stated that Brazil's form of education at the time could not integrate people into the democratization process, and that Brazil's cultural history could not provide people with the qualities appropriate to the form of democratic government. Therefore, people had to turn education into a form of cultural action. Through education, Freire believed that the Brazilian people could learn and get rid of their passive status. New attitudes and habits for their lifeworld could be formed. 
Freire focused on the democratization of Brazilian culture, and in the context of democratization, it is necessary to pay special attention to the quality and quantity of education. In 1964, about 4 million school-aged children in Brazil were unable to attend school. Of the population those over 14 years old in Brazil, there were about 16 million illiterate people. The above-mentioned phenomenon was regarded as a serious obstacle to the development of the Brazilian state and the birth of democracy at that time. This is because when the number of illiterate people decreases, the number of people participating in politics increases (Freire, 1978, 1997), which in turn would lead Brazil to democracy. Due to his efforts, Freire was arrested and imprisoned in a military coup in Brazil in 1964.

\subsection{Religious Beliefs}

Religion is an indispensable element in the lives of Brazilians. There are numerous churches and chapels in Brazil. And frequent religious celebrations entertain people who participate. Almost $90 \%$ of the country's population is Roman Catholic and Brazil has more Roman Catholics than any other country in the world. In addition to faith in Roman Catholicism, Brazilians also follow Christianity, Buddhism, and Judaism. Brazil has adopted a tolerant attitude toward religion and allows the existence of various religions (Bender, 1990). In other words, people in Brazil are free to choose different religious beliefs.

Catholic doctrine is concerned with respect for God, peace and love. However, foreign missionaries and European immigrants have affected Brazil's religious beliefs and behaviors. The church has become an important place for the spread of European culture. According to Freire's analysis, the traditional church represented the concept of the dominant class, passing only the capitalist concept of humanity, advocating the maintenance of the status quo, and opposing drastic social reform; at the same time, even if the church is neutral in the relationship between history and political action, the actions of the church have often been beneficial to elite members. Furthermore, the church is a place dominated by culture, so Freire advocated the role of a revolutionary church to truly liberate the oppressed (Freire, 1985; Wang, 1990). Furthermore, the extreme alienation and irrationality in the real world in Latin America caused growing poverty, inequality and the exoduses of many poor people. The voices advocating equality, people's rights and liberation of social reality became the theme of history. Within liberation theology, "freedom", "equality" and "justice" are not just states of human life. They can be regarded as historical values and goals. They are rooted in human nature and God in this world. The divinity shown in humans is the inevitable fate and eternal requirement of human beings. In the language of theology, the free nature of human beings and the search for liberation are not simply human requirements or practices in the sense of history, but the fundamental way of human existence (Zhang \& Chen, 2000).

Affected by liberation theology, Freire's critical pedagogy also liberates people. Freire was concerned with respect for God, peace and love. He was also concerned with the liberation of humanity. The core idea of Freire's political science and pedagogy was a philosophical vision of liberated humanity. The nature of this vision was based on the respect of life, and the hope and vision of the future (Giroux, 1985). This concept is consistent with theological concept of transforming obstructions that hinder the nature of human freedom. Liberation theology was an important trend in Catholic and Protestant churches throughout Latin America, Brazil not excluded. This movement was mainly to fight for justice for the poor and the oppressed. The clergy and their followers became social activists who actively participated in social and political movements (Bender, 1990).

\section{Discussion}

Paulo Freire was a complex pedagogical thinker, and his work demanded ongoing reflection and discussion. Although the years following Freire's death in 1997 have brought new problems and challenges, Freirean ideas appear to be as relevant today as they ever have been. Over the past twelve years, numerous books and papers on Freire's theory and practice have been published. Freire's written words have continued to live on long after his death, with a number of books being released posthumously (Roberts, 2010).

First, in the historical and political analysis conducted by Freire, his basic argument was that Brazil's immature democracy was mainly due to the type of colonization. This type of colonization can be said to be "predatory colonization", which uses slave labor and the abuse of power to slaughter elites, leading to the "muteness" Brazilian people and making them unable to speak for themselves. Therefore, the immaturity of democracy actually stems from cultural complexes. Even Freire takes the exploitation of slave labor as a basic feature of his social analysis (Because of slave labor), a series of obstacles have arisen, and the democratic experience, awareness, participation and self-governance has become less likely to form (Torres, 2014).

Freire's first book, "Education as the Practice of Freedom", can be said to have considerable influence, and the book is also related to his doctoral thesis at Recife University in 1959 (Torres, 2014). His second book "Pedagogy of the Oppressed", which is his most famous book, established Freire's international authority on pedagogy. This book was first published in 1968 and the English version was published in 1970. The content of the 
book is deeply rooted in the specific context and describes the reaction of labor and the middle class. These are Freire's direct or indirect observations when he was actually engaged in education. More precisely, this book is Freire's philosophical reflection on his educational practice, which is critical and radical, so the core of this book is that education is the practice of freedom (Elias, 1994; Freire, 1998b).

The Pedagogy of the Oppressed is animated by authentic humanism (and not humanitarian) and generously presents itself as a pedagogy of man. Pedagogy, which begins with the egoistic interests of the oppressors (an egoism cloaked in the false generosity of paternalism) and makes of the oppressed the objects of its humanitarianism, itself maintains and embodies oppression. It is an instrument of dehumanization (Aronowitz, 1981). The Pedagogy of the Oppressed outlines a theoretical analysis of revolutionary education. What Freire showed is the awakening to the existence of social structure. And the social structure includes economics, education, and religion. In education, the vast majority of illiterate people in Brazil could be described as the proletariat, and the proletariat people themselves were often too docile, so they could not master the role they had to play in history. Therefore, it was impossible to transform or even create a living world. Lenin referred to the proletarian people themselves as often too docile to control the role they must play in history. In other words, they cannot intervene in their own history, and thus create history, and cannot transform or even create the world they live in. However, Lenin pointed out that education can be used to stimulate a critical spirit among the proletarian masses (Berlin, 1969).

During his time in prison in 1964, Freire started to write his first book, Education as the Practice of Freedom, which was published in Chile in 1969, when Freire was in exile. The edition Education as the Practice of Freedom is included in the first part of the book Education for Critical Consciousness (the book consists of two parts). Furthermore, Extension and Communication is a short-form version (written in 1968), included in the book Education for Critical Consciousness (Part 2), and is also important and non-negligible work. Extension and Communication distinguishes between expansion plans and communication plans. This writing also exposes the epistemology supports for Freire's educational theory. Freire refused to use both idealism and materialism to explain people's cognitive process. He pointed out a kind of dialectical theory planted in human cognition, and this human cognition exists in practice. This short work clearly demonstrates the importance of knowledge theory in Freire's educational philosophy (Elias, 1994; Freire, 1994; Goulet, 1997; Taylor, 1993).

A few years later, Brazil reached a population of 110 million people in 1970. At that time, one-third of the adult population was illiterate. These illiterate people lived in the cultural mythology created by oppressors and considered themselves incompetent. Therefore, in this case, it was impossible to read and write, and it is not easy to use Portuguese (Brazil is the only country in Latin America and South America that uses Portuguese). Based on this factor, in adult education in Brazil, literacy education has become an important goal to be pursued (Freire, 1985; Zhan, 1994), and this was also the goal that Freire had been striving for throughout his life. In general, illiteracy not only hinders social economic order, but also deepens injustice. These injustices have profound consequences. The illiterate person cannot make decisions or participate in politics on his own, and does not even know that his actions can transform the unreasonable phenomena of the living world. Therefore, illiteracy has also hindered the development of democracy in Brazil (Freire, 1985; Freire \& Macedo, 1987), which has, in turn, hindered educational development in Brazil.

Freire never proposed a radical political revolution. He declared that the true revolutionary intention should be to liberate the people and make the people live more freely. And for the distinct class of Brazil, as Freire put it: We live together for hunger, but we don't need classes. We hope that we can improve this social structure to attain a perfect society (Elias, 1994; Freire, 1985; Kozol, 1978; Mackie, 1981).

\section{Implications for Education}

This paper takes on an important project, which is to shed light on the social context (1950s-1970s) of Freire's critical pedagogy. The author provides a well-researched summary of the historical, political, social structure, economic, educational and religious context of Brazilian society. After exploring the influence of the Brazilian social context (1950s-1970s) on Freire's critical pedagogy, this paper has the following implications for education.

\subsection{Education Should Build a More Just Society}

Countries should be committed to the development of education, and education can enhance people's ability to understand the world and participate in politics. Students should have a broad base of knowledge, independent thinking and problem-solving ability (Shih, 2019).

Education can make politics more democratic, the country more progressive and build a more just society. As stated by Taylor (1993: 2): Freire's concern is in line with the needs of humanity, and the focus is on the development of a just society. In other words, the subject that Freire cares about is how to build a more just society. The topic of concern is how to build a more humane society. In fact, Freirean-based literacy programs involve an examination of society's hidden economies of power and privilege and how these help to inform students' subjectivities. Too often words that are intimately connected to social relations and cultural power recapitulate the asymmetrical relations of power and 
privilege of the larger society. As social agents, we are geopolitically arranged by dominant literacies (McLaren \& Tomaz Tadeu da Silva, 1993). And when the specific situation of oppression is transformed, people can achieve a more just society (Freire, 2000).

\subsection{Education Is to Let Students Change from "Being for Others" to "Being for Themselves"}

"To be a good liberating educator," Freire wrote to literacy teachers in Chile in 1971, "you need above all to have faith in human beings. You need to love. You must be convinced that the fundamental effort of education is to help with the liberation of people, never their domestication. You must be convinced that when people reflect on their domination they begin a first step in changing their relationship to the world (Shor, 1993)." Thus, people can look their lifeworld with a more critical perspective. Education is to let students change from "being for others" to "being for themselves." And it hopes that the individual will awaken one's own critical consciousness based on education, and then view the social reality with a more critical perspective to achieve his liberation, and have his freedom. According to Clark, in higher education systems driven by student satisfaction, there has been a recent push towards more student-centred methods of teaching, such as collaborative learning and seminar discussions, despite an increase in student numbers. In contrast, some academics defend the transformative and educative possibilities of the lecture by challenging its conception as "banking education", asking us to reflect on the purpose of education in a way that calls into questioning our assumptions about the transmission of information through lecturing. We should consider whether or not a lecture can engage in critical pedagogy by interrupting previous ways of thinking and being. This also begs the question, is a lecture enough to arouse critical pedagogy? Let students change from "being for others" to "being for themselves." Let students fight and change the social structure that once oppressed them. Let students liberate themselves from the bondage of silent culture and meet the needs of students' humanity and develop a more just society.

\subsection{Pay Much Attention to Justice in the Teacher-Student Relationship}

Pay much attention to justice in the teacher-student relationship. Plato believed that "justice" is a virtue, and everyone must have duty and necessity to practice the virtue of "justice." Therefore, teachers have a duty and obligation to practice the virtue of "justice" in educational practice. American education scholar W. Waller pointed out that the school is a closed social interaction system. At any time, both teachers and students resist in the process of teaching interaction. Waller began to pay attention to the study of teacher-student relationship in the classroom.
Although Waller published the book "The Sociology of Teaching" in 1932 elaborating this argument, the study of the teaching process has still been largely ignored by sociologists (Banks, 1972). However, if the teacher-student relationship is broken, education will fall into the worst of states (Freire, 1998a). Because the relationship between teachers and students often affects the success of education, when education pursues innovation and excellence, the discussion of the relationship between teachers and students cannot be ignored. In the past, teaching and learning were indoctrinated. In this kind of indoctrinating teaching activity, the teacher-student relationship often showed vertical characteristics. In other words, the teacher is the subject of teaching activities while the students become the object of teaching activities. When teachers become the main body of teaching activities, teachers themselves are often reduced to authoritarian educators.

However, an authoritarian (teacher) tends to deny the role of others (student) in the historical process (Freire, 1998c). Freire (2000) pointed out: education is to break the teacher-student relationship of the vertical patterns characteristic of banking education. That is to say, problem-posing education begins with the solution of contradictions between teachers and students, and only after overcoming the above contradictions, can the freedom of education be achieved. Therefore, students are bound to become the marginalized people in learning activities, and cannot transform the unreasonable reality in the teaching process. As such, justice in the teacher-student relationship is ignored.

\section{Conclusions}

Many educational changes occurring during the 20th century were brought about by historical facts, social movements, and political agendas. Politics is a starting point of changes in education. Comments about peace, imperialism, racism, feminism, and other social issues came from different areas of the world, and individuals, like Apple in the USA and Freire in Brazil (Riasati, \& Mollaei, 2012). In Brazil, during the era in which Freire lived, the difference between the rich and poor was tremendous. The poor were marginalized. After all, for those who have completely been marginalized, after a thorough change, they are no longer merely objects passively responding to changes in their lives. On the contrary, it is highly probable that people will decide to fight and change the social structures that once oppressed them and will no longer allow the oppressors to make them less aware of the structure of existence (Freire, 1985; Shaull, 1993).

Regarding the influence of the Brazilian social context (1950s-1970s) on Freire's critical pedagogy, Freire believed that to make Brazilian society more democratic, 
we must start with irrational phenomenon by fighting hunger, unemployment, the health crisis and obstacles to education. This study looked at Paulo Freire's critical pedagogy based on the historical, political, cultural, social, economic, educational, and religious aspects, and hoped to rebuild the Brazilian social context (1950s-1970s) in which Freire lived at that time. The gap between the rich and poor was large. The educational situation in Brazil at that time was arguably high on illiteracy and low on education. And even worse, literacy became an element of citizenship (Freire, 1998b). Therefore, under such circumstances, the vast majority of illiterate people in Brazil did have the right to vote; that is, they could not obtain citizenship to participate in politics. Thus, illiterate people were unable to fulfill their rights and could not participate in the transformation of their society. Brazil had become a closed society and lacked democratic experience in politics (Elias, 1994; Freire, 1985). Finally, Freire's thoughts are influenced by liberation theology, and he hoped to liberate illiterate people in Brazil, and let them live more freely to create a more just Brazilian society.

In conclusion, this papers conveys the persistent and extreme inequality in Brazil, which is crucial to approach Freire's critical pedagogy. In addition, this study notes that the high rate of illiteracy in Brazil influenced Freire's focus on literacy, and the particular and unequal social structure and distribution of literacy/illiteracy in Brazil impacted Freire's radical conception of critical pedagogy.

\section{REFERENCES}

[1] Aronowitz, S. (1981). Preface. In H. A. Giroux (Ed.), Ideology, culture \& the process of schooling(pp.1-4). Philadelphia, PA: Temple University Press.

[2] Banks, O. (1972). The sociology of education. London, UK: Batsford.

[3] Bender, E. (1990). Brazil. New York, NY: Chelsea House.

[4] Berlin, I. (1969). Four essays on liberty. Oxford, England: Oxford University Press.

[5] Carnoy, M. (1997). Foreword. In P. Freire (Ed.), Pedagogy of the heart(pp.7-16). New York, NY: The Continuum.

[6] Data Center for Africa and Latin America (1963). The economy of Brazil. Taipei City: Data Center for Africa and Latin America.

[7] Elias, J. L. (1994). Paulo Freire: Pedagogue of liberation. Malabar, FL: Krieger.

[8] Esteva, G., Stuchul, D. L. \& Prakash, M. S. (2005). From a pedagogy for liberation to liberation from pedagogy. In C. A. Bowers \& F. Appffel-Marglin (Eds), Rethinking Freire: Globalization and the environmental crisis (pp.13-30). New York, NY: Routledge.
[9] Freire, P. (1978). Pedagogy-in-process: The letters to Guinea-Bissau. New York, NY: The Seabury Press.

[10] Freire, P. (1985). The politics of education: Culture, power, and liberation. South Hadley, MA: Bergin \& Garvey.

[11] Freire, P., \& Macedo, D. (1987). Literacy: Reading the word and the world. London, England: Routledge \& Kegan Paul.

[12] Freire, P. (1993). Pedagogy of the city. New York, NY: The Continuum.

[13] Freire, P. (1994). Pedagogy of hope: Reliving pedagogy of the oppressed. New York, NY: The Continuum.

[14] Freire, P. (1996). Letters to Cristina: Reflections on my life and work. London, England: Routledge.

[15] Freire, P. (1997). Education for critical consciousness. New York, NY: The Continuum.

[16] Freire, P. (1998a). Teachers as cultural workers: Letters to those who dare to teach. Boulder, CO: Westview Press.

[17] Freire, P. (1998b). Pedagogy of freedom: Ethics, democracy, and civic courage. New York, NY: Rowman \& Littlefield.

[18] Freire, P. (1998c). Politics and education. Los Angeles, CA: University of California.

[19] Freire, P. (2000). Pedagogy of the oppressed. New York, NY: The Continuum.

[20] Giroux, H. A. (1985). Introduction. In P. Freire (Ed.), The politics of education: Culture, power, and liberation (pp.xi-xxv). South Hadley, MA: Bergin \& Garvey.

[21] Giroux, H. A. (2010). Rethinking education as the practice of freedom: Paulo Freire and the promise of critical pedagogy. Policy Futures in Education, 8(6), 715-721.

[22] Goulet, D. (1997). Introduction. In P. Freire (Ed.), Education for critical consciousness (pp.vii-xiv). New York, NY: The Continuum.

[23] Guilherme, M. (2017). Freire's philosophical contribution for a theory of intercultural ethics: A deductive analysis of his work. Journal of moral Education, 46 (4), 422-434.

[24] Hall, M. M., \& Garcia, A. G. (1989). Urban Labor. In M. L. Conniff \& F. D. McCann (Eds.), Modern Brazil: Elites and masses in historical perspective (pp.161-191). Lincoln, NE: University of Nebraska Press.

[25] Huang, Z. C. (2003). The Pedagogy of the Oppressed: Freire's theory and practice of liberation education. Beijing City: People's Education Press.

[26] Haussman, F., \& Haar, J. (1978). Education in Brazil. Hamden, CT: The Shoe String Press.

[27] Havighurst, R. J., \& Moreira, J. R. (1965). Society and education in Brazil. Pittsburgh, PA: University of Pittsburgh Press.

[28] Kozol, J. (1978). Foreword. In P. Freire (Ed.), Pedagogy-in-process: The letters to Guinea-Bissau (pp.1-4). New York, NY: The Seabury Press.

[29] Mackie, R. (1981). Literacy and revolution: The pedagogy 
of Paulo Freire. New York, NY: The Continuum.

[30] Mitchell, S. (1981). Introduction. In S. Mitchell (Ed), The logic of poverty: The case of the Brazilian Northeast (pp.1-9). London, England: Routledge \& Kegan Paul.

[31] McLaren, P., \& Tomaz Tadeu da Silva (1993). Decentering pedagogy: Critical literacy, resistance and the politics of memory. In P. McLaren \& P. Leonard (Eds.), Paulo Freire: A critical encounter (pp.47-89). London, UK: Routledge.

[32] Riasati, M. J., \& Mollaei, F. (2012). Critical Pedagogy and Language Learning. International Journal of Humanities and Social Science, 2(21), 223-229.

[33] Roberts, P. (2010). Paulo Freire in the 21st century: Education, dialogue, and transformation. London, UK: Paradigms Publishers.

[34] Shor, I., \& Freire, P. (1987). A pedagogy for liberation: Dialogues on transforming education. South Hadley, MA: Bergin \& Garvey.

[35] Shaull, R. (1993). Foreword. In P. Freire (Ed.), Pedagogy of the oppressed (pp.11-16). New York, NY: The Continuum.

[36] Shih, Y. H. (2019). An examination of the functions of a general education art curriculum in universities. Policy Futures in Education, 17(3), 306-317.

[37] Shor, I. (1993). Education is politics: Paulo Freire's critical pedagogy. In P. McLaren \& P. Leonard (Eds.), Paulo Freire: A critical encounter (pp.25-35). London, UK: Routledge.

[38] Taylor, P. A. (1993). The texts of Paulo Freire. Philadelphia, PA: Open University Press.

[39] Time-Life Books (Ed) (1986). Brazil. Amsterdam, NL: Time-Life Books.

[40] Wang Yang, C. R. (1990). The research on Freire's critical adult teaching model (Unpublished doctoral dissertation). Taipei City: National Taiwan Normal University.

[41] West, C. (1993). Preface. In P. Leonard \& P. McLaren (Eds.), Paulo Freire: A critical encounter (pp.xi-xv). London, UK: Routledge.

[42] Zhan, D. L. (1994). Brazilian adult literacy education campaign. Adult Education, 31, 30-34.

[43] Zhang, S. L., \& Chen, X. C. (2000). Liberation theology. Taipei City: Yang Zhi. 